\title{
THE GERMAS INFLUENCE OF GYMN BRAIN COMBINATION EXERCISE ON THE STRESS LEVEL OF XI ADOLESCENT STUDENTS IN SMK 17 PARE
}

\author{
Moch Maftuchul Huda \\ School of Nursing, STIKES Karya Husada Kediri \\ Corresponding e-mail : mochmhuda@gmail.com
}

\begin{abstract}
BACKGROUND : Stress is an inevitable part of everyone's life. Stress in school adolescents can result in decreased learning achievement. Therefore, it is necessary to do therapy, one of which is a combination of Germas stretching and brain exercise. This study aims to determine and prove the effect of Germas Exercise Combination Brain Gymn on the Stress Levels of Adolescent in Class XI SMK 17 Pare.

SUBJECT AND METHODE : Quasi Experiment research design, the number of samples of 40 adolescents using purposive sampling techniques, uses a stress sclae measurement tool of DASS 42 modification.

RESULTS: Almost all (90\%) of respondents' stress conditions before the intervention were in the mild stress criteria, whereas after the intervention, the majority were obtained $(55 \%)$ with mild stress criteria. Statistical test results with the Wilcoxon signed rank test ( $p$-value $=0.003$ ), means that there is an effect of Germas Exercise Combination Brain Gymn.

DISCUSSION : Stress is characterized by signs and symptoms of feeling difficult to relax, pessimistic, easily offended. Germas Exercise Combination Brain Gymn can cause the pituitary gland to stimulate the hypothalamus so that the endorphins are raised and the cortisol hormone decreases which makes the feeling relaxed and happy so that the stress decreases. Germas Exercise Combination Brain Gymn can be an alternative solution as an innovative and applicative effort to reduce stress levels that can be done easily and independently.
\end{abstract}

Keywords: Germas Exercise, Brain Gym, stress level, adolescents

\section{INTRODUCTION}

Stress is an inevitable part of human life. Stress is a process that assesses an event as something that is threatening and even dangerous and the individual responds to the event on a physiological, emotional, cognitive and behavioral level (Richard, 2010). According to Needlman, (2008) stress thhat occurs in adolescents is usually caused by several factors including biological, family, school, peer, and social environmental factors. The population of adolescents in Indonesia who are 10-24 years old is around 66.3 million people out of a total population of 258.7 million (Chandra, 2017), according to Basic Health Research data (Rikerdas, 2018) the prevalence of stress events in adolescents increases in the age by more than 15 years. About $6.1 \%$ of Indonesian people over the age of 15 experience mental emotional disorders in the form of stress, anxiety and depression. East Java Province itself adolescents who experience emotional mental disorders are (7\%). According to Priscilla (2017) globally, suicides are the second leading cause of death worldwide among $15-19$ year adolescents. 
Based on preliminary study data in the XI Pharmacy Vocational Class Bhakti Mulia Pare on October 29, 2018 there were 15 children as respondents from 40 children. They feel stress with symptoms that lead to physical, cognitive, affective responses. Percentage of physical response weariness was $60 \%$, restlessness and sleeplessness was $46.6 \%$, increasing neck and shoulder strain was $53.3 \%$, pulse rate was $33.3 \%$, decreasing appetite was $40 \%$, while response from cognitive and affective marked by daydreaming $13 \%$, hard to focus during lessons $33.3 \%$, easy to forget, difficulty in concentrating, changing emotions, changing habits and daily activities $60 \%$.

Adolescents are prone to experiencing problems and stress because adolescents are still in an unstable state and emotions have not formed fully. Adolescents, who experience stress or the burden of their mind if they try very hard, will cause stress in the brain, so that the brain's integration mechanism is weakened and certain brain parts are less functioning. Information received by the back of the brain becomes difficult to express, so people feel less successful and stress will result in reduced enthusiasm for learning and working (Feist, 2010).

The solution to help reduce stress is by doing GERMAS Stretching (Healthy Living Movement) and Brain Gymnastics training. The results of research conducted previously by providing brain training exercises on stress levels in students before and after treatment for 6 days was found that before and after given brain exercises there is a decrease in the value of stress levels (Nurdin, 2015).

Brain Gym is a series of exercises based on simple body movements. The movement was made to stimulate the left and right brain (lateral dimension), ease or relax the back and front of the brain (the focusing dimension), stimulate the feeling or emotional system, namely the midbrain (limbic) and cerebrum (dimension of concentration). In Brain Gym, there is a movement to increase energy and support a positive attitude (centering dimension) reactivating the neural connections between the body and brain so it is easy to facilitate the flow of electromagnetic energy throughout the body). Humans are chemical creatures under certain conditions at the behest of the brain, and their body produces chemicals. Producing and releasing these chemicals in times of fear and stress, the brain instructs the body to produce and release the cortisol and adrenaline hormones(Dennison, 2011).

Germas Exercise Combination Brain Gymn can reduce the cortisol and adrenaline hormones and then increase the endorphin hormone. The function of endorphins is creating a sense of well-being, comfort and safety. Germas Exercise Combination Brain Gymn can release endorphins, which calm the nerves to create a feeling of calm and peace, to help in stabilizing emotions. These substances can cause relaxation, blood pressure and declined pulse. All feeling diseases associated with pressure on our feelings such as anger, sadness and depression can be reduced or even eliminated (Harry, 2008). As a result, psychosocial and physical stress is reduced and the mind is clearer, relations between humans and the atmosphere of learning or working are more relaxed and happier (Isnaini, 2009).

It can be concluded that research on the provision of Germas Exercise Combination Brain Gymn intervention is still really needed as a contribution to reduce stress levels. Then based on the description above, the researcher wants to know the effect of Germas Exercise Combination Brain Gymn on the stress levels of adolescents in class XI of SMK 17 Pare.

The objectives of this research is to analyze the the effect of Germas Exercise Combination Brain Gymn in class XI SMK 17 Pare. 


\section{METHODS}

Based on the research objectives, researchers used a Quasi Experiment pre-post with control group design in two groups. The population in this study were 45 respondents. The sample in this study were teenagers in class XI Accounting students of SMK 17 Pare who met the inclusion criteria of 40 respondents divided by 2 namely the treatment and control group. Purposive Sampling technique is a sampling technique with certain considerations (Sugiyono, 2008). Inclusion criteria of adolescent students are willing to be the respondent. Adolescents in class XI Accounting students of SMK 17 Pare who had done physical and psychological stress scoring, with mild, moderate and severe criteria, did not have a history of psychiatric disorders, and agreed to be respondents. The research process was begun after obtaining ethical approval with the number 134 / EC / LPP / STIKES / KH / II / 2019, then the researcher conducted a research permition that had been approved by the institution leader, then provided information about the aims and benefits of the study, then requested the respondent's approval as the subject, then the researcher took a stress measurement using DASS 42 modification (depression anxiety stress scales) before the intervention. The intervention was carried out twice a week for 3 weeks within 30 minutes of each meeting. After the 3rd week intervention, the stress measurements were taken by using a modified DASS 42 (Depression Anxiety Stress Scales 42th).

\section{RESULT AND DISCUSSION}

Table 1 Distributing Frequency of Respondents by Gender Intervention and Control Groups in XI Adolescent students of SMK 17 Pare

\begin{tabular}{|c|c|c|c|c|c|}
\hline \multirow[t]{2}{*}{ NO } & \multirow[t]{2}{*}{ Gender } & \multicolumn{2}{|c|}{ Intervention Group } & \multicolumn{2}{|c|}{ Control Group } \\
\hline & & $f$ & $\%$ & $f$ & $\%$ \\
\hline 1. & Male & 1 & 5 & 3 & 15 \\
\hline 2. & Female & 19 & 95 & 17 & 85 \\
\hline & Total & 20 & 100 & 20 & 100 \\
\hline
\end{tabular}

Based on table 1, it is known that the characteristics of respondents by gender in the intervention group were almost entirely (95\%), namely 19 respondents were female.

Table 2 Distributing Frequency of Respondents by Age Intervention and Control Groups in XI Adolescent Students of SMK 17 Pare

\begin{tabular}{crrccc}
\hline NO & Age & \multicolumn{2}{c}{ Intervention Group } & \multicolumn{2}{c}{ Control Group } \\
\cline { 3 - 6 } & & $\mathrm{f}$ & $\%$ & $\mathrm{f}$ & $\%$ \\
\hline 1. & $15-16$ years & 0 & 0 & 2 & 10 \\
2. & $16-17$ years & 9 & 45 & 7 & 35 \\
3. & $17-18$ years & 11 & 55 & 11 & 55 \\
\hline & Total & 20 & 100 & 20 & 100 \\
\hline
\end{tabular}

Based on table 2, it is known that the characteristics of respondents based on age in the intervention group, the majority (55\%), were 11 respondents aged $17-18$ years.

Data analysis used Mann Whitney test because the data distribution is not normal according to Kolmogorov Smirnov normality test where the results is $\mathrm{P}<\mathrm{a}$. 
Table 3 Frequency Distribution of Stress Level Treatment and Control Groups Before GERMAS Intervention Exercise Brain Gymn Combination in Adolescents of Class XI SMK 17 Pare.

\begin{tabular}{ccccc}
\hline \multirow{3}{*}{ Stress level characteristic } & \multicolumn{2}{c}{ Intervention Group } & \multicolumn{2}{c}{ Control Group } \\
\cline { 2 - 5 } & \multicolumn{2}{c}{ Before Intervention } & \multicolumn{2}{c}{ Before Intervention } \\
\cline { 2 - 5 } & $\mathrm{f}$ & $\%$ & $\mathrm{f}$ & $\%$ \\
\hline Mild Stress & 2 & $10 \%$ & 6 & $30 \%$ \\
Moderate Stress & 18 & $90 \%$ & 14 & $70 \%$ \\
severe Stress & 0 & $0 \%$ & 0 & $0 \%$ \\
\hline \multicolumn{1}{c}{ Total } & 20 & $100 \%$ & 20 & $100 \%$ \\
\hline \multicolumn{4}{c}{ Mann Whitney test } & $p$ value 0, $118(=0,05)$ \\
\hline
\end{tabular}

Table 3 shows before the GERMAS intervention Brain Gymn exercise combination in the treatment group, that almost all (90\%) 18 respondents had mild stress criteria and a small portion (10\%) 2 respondents with soft stress criteria. While the control group was almost entirely (70\%) 14 respondents were mild stress criteria and a small portion (30\%) 6 respondents were soft stress criteria. Mann Whitney test results were obtained 0.118 results so that it can be concluded that if $p$ value $>a$, it shows that the two groups before treatment there was no difference in stress levels before the GERMAS exercise combination of Brain gymn.

Table 4 Characteristic Distribution of Stress Level After GERMAS Exercise Combination Brain Gymn in the Treatment and Control Group of Adolescent students Class XI SMK 17 Pare.

\begin{tabular}{ccccc}
\hline \multirow{3}{*}{ Stress level characteristic } & \multicolumn{2}{c}{ Intervention Group } & \multicolumn{2}{c}{ Control Group } \\
\cline { 2 - 5 } & \multicolumn{2}{c}{ After Intervention } & \multicolumn{2}{c}{ After Intervention } \\
\cline { 2 - 5 } & $\mathrm{f}$ & $\%$ & $\mathrm{f}$ & $\%$ \\
\hline Mild Stress & 11 & $55 \%$ & 4 & $20 \%$ \\
Moderate Stress & 9 & $45 \%$ & 16 & $80 \%$ \\
Severe Stress & 0 & $0 \%$ & 0 & $0 \%$ \\
\hline Total & 20 & $100 \%$ & 20 & $100 \%$ \\
\hline \multicolumn{2}{c}{ Mann Whitney test } & $p$ value $0,024(\alpha=0,05)$ & \\
\hline
\end{tabular}

Table .4 shows that in the treatment group after GERMAS intervention was given, the combination of brain gymn was mostly (45\%) 9 respondents with mild stress criteria, (55\%) 11 respondents with mild stress criteria. In the control group after being given the intervention was mostly (80\%) 16 respondents with mild stress criteria and a small proportion (20\%) 4 respondents with mild stress criteria. Mann Whitney test results were obtained 0.024 so it was concluded that in two treatment and control group there were differences after the intervention.

Based on the frequency calculation of treatment group, it shows that there is a change in the level of stress with the results before the intervention conducted, it is almost entirely (90\%) mild stress, after the intervention is most (55\%) mild stress.

Based on the calculation of the frequency of the control group, it shows that there is a change in the level of stress with the results before the intervention is almost entirely (7-\%) mild stress, after the intervention is almost entirely $(80 \%)$ mild stress. 
Table 5 Frequency Distribution of Treatment and Control Groups Before and After GERMAS Intervention Exercise Brain Gymn Combination in Adolescents Class XI Accounting SMK 17 Pare

\begin{tabular}{lcccccccc}
\hline \multirow{2}{*}{$\begin{array}{c}\text { Stress Level } \\
\text { Characteristic }\end{array}$} & $\begin{array}{c}\text { Before } \\
\text { intervention }\end{array}$ & \multicolumn{2}{c}{ After intervention } & \multicolumn{2}{c}{$\begin{array}{c}\text { Before } \\
\text { intervention }\end{array}$} & After intervention \\
\cline { 2 - 10 } & $\mathrm{f}$ & $\%$ & $\mathrm{f}$ & $\%$ & $\mathrm{f}$ & $\%$ & $\mathrm{f}$ & $\%$ \\
\hline Soft Stress & 2 & $10 \%$ & 11 & $55 \%$ & 6 & $30 \%$ & 4 & $20 \%$ \\
Mild Stress & 18 & $90 \%$ & 9 & $45 \%$ & 14 & $70 \%$ & 16 & $80 \%$ \\
Hard Stress & 0 & $0 \%$ & 0 & $0 \%$ & 0 & $0 \%$ & 0 & $0 \%$ \\
\hline Total & 20 & $100 \%$ & 20 & $100 \%$ & 20 & $100 \%$ & 20 & $100 \%$ \\
\hline Wilcoxon test & $p$ value $0,003(\alpha=0,05)$ & $p$ value $0,317(\alpha=0,05)$ & &
\end{tabular}

Based on table 5.5, the stress level after GERMAS exercise combination of brain gymn in the treatment group before and after the intervention was $p=0.003$, and the control group before and after without intervention was $p=0.317$ (there is no difference in the level of stress before intervention). The treatment group had the effect $(p=0.003)$ GERMAS exercise combination of brain gym on the stress levels of adolescents in class XI Accounting students of SMK 17 Pare.

The results of this study, with data processing using Wilcoxon test in the intervention group, used to compare between pre-test and post-test. This analysis yields a p value of 0.003 ( $a=$ 0.05 ) meaning that there is an effect of Germas Exercise Combination Brain Gymn on the stress level of adolescent accounting students in XI grade of SMK17 Pare. This research was conducted three weeks and with $2 x$ meetings in a week with a total of $6 x$ meetings. In the control group without intervention the $p$ value was $0.317(>a 0.05)$ meaning that there is no difference in the stress level of adolescents in class XI in Accounting SMK 17 Pare.

The results of research on adolescent stress levels have changed after intervening Germas Exercise Combination Brain Gymn namely warming up movement aims to avoid injury before carrying out core activities, facilitate blood flow through active muscles, reduce the presence of muscle tension, core movements aim to increase delivery oxygen, reduce physical and emotional stress and relaxe the nape of necks and shoulders, increase flexibility, the movement of cooling dow, and maintain the limb balance to be relaxed. This study proves there is a change or effect on the treatment group because respondents who are concerned with this study are very enthusiastic, focused and willing to work together to follow the procedures that have been done in doing Germas Exercise Combination Brain Gym given.

\section{CONCLUSION AND RECOMMENDDATION}

Conclusion from the result above are :

1. Stress levels in the treatment and control groups before the intervention are almost entirely stressed.

2. Stress levels in the treatment group after the intervention experienced soft stress while those in the control group without intervention experienced mild stress

3. There is an effect of Germas Exercise Combination Brain Gymn on accounting adolescents of class XI SMK 17 Pare

Some of recommendation of these study are :

1. Germas Exercise Combination Brain Gymn becomes one of the choices in overcoming adolescent stress as an innovative and applicative effort. 
2. Germas Exercise Combination Brain Gymn can be used as an additional alternative intervention strategy in conducting nursing care in adolescents with stress problems

\section{REFERRENCE}

Arikunto, S. 2008. Research Procedures. Jakarta: Rineka Cipta.

Asrori, M. 2008. Adolescent Psychology. Jakarta: Earth Literacy.

Hawari, D. 2006. Anxiety and Depression Stress Management. Jakarta: Second Edition

Hurlock, E.B. 1999. Developmental Psychology. Jakarta: Erlangga.

Hurlock, E.B. 2006. Developmental Psychology: An Approach Throughout the Life Span. Fifth Edition. Subtitles: Istiwidyanti and Soedjarwo. Jakarta: Erlangga.

Hurlock, E.B. 2007. Developmental Psychology: An Approach Throughout the Life Span. Sixth Edition. Subtitles: Istiwidyanti and Soedjarwo. Jakarta: Erlangga.

Hurlock, E.B. 2008. Developmental Psychology: An Approach Throughout the Life Span. Seventh Edition. Subtitles: Istiwidyanti and Soedjarwo. Jakarta: Erlangga.

Mar'at. 2010. Developmental Psychology. PT Youth Rosdakarya.Bandung. 6th edition, pp. 189-210

Nasution. 2007. Stress in Adolescents, accessed from the journal October 19, 2018. 2008. Stress in Teens. USU Respiratory, 21-23.

Notoadmojo, S. 2005. Health Research Methodology. Jakarta: Rineka Cipta.

Nurdin. 2015. The Effect of Brain Exercise on Stress in Santri Madrasah. Yogyakarta, accessed from the journal October 19, 2018.

Nursalam. 2008. Concepts and Application of Nursing Research Methodology. Surabaya: Salemba Medika.

2013. Concepts and Application of Nursing Research Methodology. Surabaya: Salemba Medika.

Olvista.2017. http://olvista.com/10-benefits-training-training-stretching/, accessed 10 November 2018.

Rahayu.2017. Brain Gym Against Stress Levels in Nursing Students of the Health Sciences Faculty of Kadiri University, accessed from the journal October 19, 2018.

Rasmun. 2004. Stress, Coping and Adaptation. First edition.

Basic Health Research (Rikerdas). 2018. Indonesian Ministry of Health's Health Research and Development Agency 2018. Accessed October 19, 2018, from

http://www.depkes.go.id/resources/download/geneal/Hasil\%20Riskeras\%20187.pdf.

Salama.2018. Effects of Gymnastics Against Stress Levels. Pontianak, accessed from the journal 19 October 2018.

Santrock, J.W. 2013. Adolsence (Youth Development). The University of at

Dallas: Times Mirror higher Education.

Santrock, J.W. 2013. Life Span Defelopment (translation). Boston Mc Graw Hill.

Sarwono. 2015. Adolescent Psychology. Jakarta: 17th print.

Siswanto. 2007. Book of Mental Health Concepts, Coverage and Development. Yogyakarta.

Soetjiningsih. 2004.Buku Teaching and Growth Youth and its problems.

Jakarta: Sagung Seto.

Soetjiningsih. 2007. Adolescent Growth and Problems. Jakarta: CV Sagung Seto.

Sugiyono 2009. Educational Research Methods (Quantitative Approach, Quality 
and R\&D). Bandung: Alfabeta.

Syamsu, Y. 2004. Child Development and Adolescent Psychology. Bandung: PT. Teen Rosdakarya.

Syamsu, Y. 2007. Psychology of Child and Adolescent Development. Bandung: Rosda Karya.

Wartakesmas. 2018. GERMAS (Healthy Living Community Movement) Ministry of Health Republic of Indonesia in 2017. Issue 1.

Zulkifli, L. 2003. Developmental Psychology. Bandung: PT Remaja Rosdakarya 